\title{
ENHANCEMENT OF SODIUM
} INTESTINAL SECRETION IN RELATION TO ABSORPTION IN MALNOURISHED RATS. Hyperosmolar challenge

\author{
Rebeca C de ANGELIS*, José Vicente Martins CAMPOS ${ }^{+}$, Regina N. ROGANO**, Geza G. GIULI**, \\ Ilza C. M. TERRA**, Julieta H. SCIALFA*** and Itamar KLEMPS-FILHO***
}

\begin{abstract}
Two experimental models were tried in young malnourished rats in order to study effect of an hyperosmolar challenge in the small intestine on the bi-directional fluxes of sodium. Weanling rats were fed with energy restricted diets. In model I $1 \mathrm{~mL}$ of $\mathrm{NaCl} 900 \mathrm{mOsm} / \mathrm{kg}$ was introduced in the small intestine of the rats and left from 5 up to 70 min, in order to determine the moment of higher net $\mathrm{Na}^{+}$secretion, which occurred at $10 \mathrm{~min}$. In model II, the bi-directional fluxes of $\mathrm{Na}^{+}$ and $\mathrm{Cl}^{-}$were studied using $\mathrm{NaCl}$ or mannitol $900 \mathrm{mOsm} / \mathrm{kg}$ under the effect of mecholil, atropine or 2-4 dinitrophenol, for $10 \mathrm{~min}$. Mecholil decreased the $\mathrm{Na}^{+}$absorption enhancing the net secretion. Control rats were used as reference. In the restricted diets animals occurred an increase of the net secretion stimulated by $\mathrm{NaCl} 900 \mathrm{mOsm} / \mathrm{kg}$, and this effect was enhanced by mecholil. It is suggested that in malnutrition there is an impairment in $\mathrm{Na}^{-}$intestinal absorption.
\end{abstract}

HEADINGS - Intestinal secretions. Nutrition disorders. Sodium. Intestinal absorption. Rats.

Professora de Química pela Universidade de São Paulo. Nutricionista registrada (Nutrition Society, Inglaterra).

** Biologistas. Doutoras em Biologia pela Universidade de São Paulo.

*** Técnicos. Instituto de Ciências Biomédicas da Universidade de São Paulo

$+\quad$ In Memoriam

Endereço para correspondência: Dr. Ruben C. de Angelis - Al. Min. Rocha Azevedo, 644 - apto. 104 - 01410-000 - São Paulo, SP 
In spite of the remarkable progress related to hydrosmotic effect on the epithelial apical membrane, the role of osmoreceptors, intracellular modulation of secretory mechanism and paracellular permeability underlying mechanism involving osmoregulation remain unclear ${ }^{(4)}$. New approaches are necessary for a better understanding of such a network of events with emphasis of malnutrition and diarrhea syndromes.

In malnutrition, a condition the enhances liability to contract and maintain diarrhea ${ }^{(15)}$ osmoregulation can be affected and consequently will impair mucosal net transport of solute and solvent. In this situation, morphological and functional changes in small intestine already registred by several investigators in animals or in human beings ${ }^{(11)}$ could be contribute to manager the mucosa capacity under osmolar loads.

The purpose of this study was to test and speculate the osmoregulation capacity of the small intestine in malnourished rats under intraluminal hyperosmolar challenge. Several natural and commercial soups, juices, beverages presented osmolality ranged from 240 to more than $2000 \mathrm{mOsm} / \mathrm{kg}^{(18)}$. This study was performed with solutions of $900 \mathrm{mOsm} / \mathrm{kg}$. In model I it was determined the effect of hyperosmolality for 70 minutes in order to obtain the best conditions for this study. In model II a study of an osmotic perturbation was induced by absorbable ion, sodium, or by non-absorbable mannose loads.

Cholinergic, anticholinergic and antimetabolic interferences were studied designed to elucidate specific influences in the bidirecional fluxes of fluid and electrolytes. The malnutrition was attained by feeding the animals with an energyrestricted diet.

\section{MATERIAL AND METHODS}

Animals - Young male normal rats (Albinus, Wistar) of average initial weight of $62 \pm 3 \mathrm{~g}$ (offsprings of 35 days) were used in the experiments of model I and II (total 220 rats).

Diets - the components of diets in $\mathrm{g} / 100 \mathrm{~g}$ we the following:

1. Control-diet (Co)

Casein 25.0, complete as reference ${ }^{(5)}$. The animals were fed ad libitum.

2. Energy-restricted diet (R)

The same Co composition, but restricted to $50 \%$ of the average total intake that was consumed by control group. Restricted at $50 \%$.

\section{Intestinal experiment design}

The animals were fed for 15 days with the different diets. After an overnight fasting the animals were anestethized with ether, the abdomen was opened and a segment of the small intestine was isolated by two ligatures: the first one at the Treitz, and the second one just at the ileum-cecum valve, Through a small opening just below the Treitz-tie a narrow polyethylene tube was inserted and $1 \mathrm{ml}$ of the hyperosmolar solution $(\mathrm{NaCl}$, or mannitol) was gently introduced into the lumen. The tube was than retired under the protection of new tie in order to avoid solution reflux. Immediately the abdomen was closed by suture and the animal left to wake up.

After the programmed period of time, the rat was anestethized again with ether, and the whole small intestine between ties was removed. Its contents were squeezed out into a volumetric tube ${ }^{(6)}$. The intestinal collected volume was measured and completed to $10 \mathrm{ml}$ with de-ionized water, filtered in paper and kept at $4^{\circ} \mathrm{C}$ till determinations.
Influence of cholinergic, anticholinergic, or metabolic inhibitor during hyperosmolar challenge: mecholil (acetylB methycholine (Mch)), was used in an i.m. injection of $375 \mathrm{mg} / 0.1 \mathrm{~mL}$; atropine A was used i.m. (0.1 mg/0.1 mL); 2-4-dinitrophenol (D) was introduced in the intestinal lumen of the animal $\left(1 \times 10^{-3} \mathrm{mM} / 0.1 \mathrm{~mL}\right)$. All these drugs when used, were injected (Mch, A) or introduced (D) in the lumen immediately before the introduction of the hyperosmolar solution in the small intestine.

\section{Determinations}

Sodium by Flame-Photometer (Evand Electroselenium); chloride by the reaction with $\mathrm{AgNO}_{3}$ and $\mathrm{KSCN}$ using ferric alumen as an indicator ${ }^{(1)}$. Osmolality by the Fiske osmometer (model G.66)

\section{Model I}

Rats were fed with $\mathrm{R}$ diet for 15 days, when they attained around $80 \mathrm{~g}$ of corporal weight. The purpose of this experiment was to determine the period of time of maximum net secretion of sodium after introduction of hyperosmolar $\mathrm{NaCl}$ solution in the small intestine of the above mentioned animals. Periods of 5 up to $70 \mathrm{~min}$ were tried. Each period was essayed in 10 rats. The maximum net secretion period was called "maximum accumulation period" (MAP). A group of 10 rats were fed Co diet in order to determine their daily ad libitum food intake (total 80 rats).

\section{Model II}

Rats were fed $\mathrm{R}$ diet for 15 days. As normal pattern reference, animals fed Co diet were used. At the established MAP, cholinergic, anticholinergic and metabolic inhibitor drugs, isolated or intercorrelated were used as a tool for the interpretation of the involved 
mechanisms. The hyperosmolar solutions used were $\mathrm{NaCl}$ or mannitol $(900 \mathrm{mOsm} / \mathrm{kg})(10$ animals/group, total 140 rats).

\section{RESULTS}

\section{Model I}

Different periods of time were studied in order to determinate the moment of the maximum net secretion (accumulation) of $\mathrm{Na}^{+}$ and fluid in the small intestine of malnourished rats as an effect of the hyperosmolar challenge of $\mathrm{NaCl}(900 \mathrm{mOsm})$ (Table 1, Fig 1). Since the first minuted there was a net secretion of sodium for $20 \mathrm{~min}$, and the MAP occurred at $10 \mathrm{~min}$. Nevertheless there was a net absorption of $\mathrm{Cl}^{-}$since $5 \mathrm{~min}$. A net absorption for $\mathrm{Na}^{+}$was observed only after $30 \mathrm{~min}$, when osmolality reached a value of $325 \mathrm{mOsm} / \mathrm{kg}$. Accumulation (J net) was taken from the differences between initial and final luminal content based on our previous observations (not published) that rats after an overnight fasting presented insignificant $\left[\mathrm{Na}^{+}\right]$concentration in the intestinal content.

\section{Model II}

In order to collect more informations about the possible mechanism of intestinal net secretion of sodium and fluid under hypertonic perturbation, animals were previously injected with na i.m. dose of a cholinergic Mch solution, simultaneously or not with A or D drugs as described in Material and Methods. This study was performed under the hypertonic effect of $900 \mathrm{mOsm} / \mathrm{g}$ solution of $\mathrm{NaCl}$ or mannitol, in 10 min. A control group was maintained for comparation. The average body weight variation of both groups: Co and $\mathrm{R}$, are presented in Table 2.

In Table 3 are shown the results of sodium and chloride accumulation.
Table 1 - Net final accumulation of $\mathrm{Na}^{+}$and $\mathrm{Cl}^{-}$, and osmolality in small intestine of malnourished (restricted diet) rats after the introduction of $1 \mathrm{~mL}$ hyperosmolar $\mathrm{NaCl}(900 \mathrm{mOsm} / \mathrm{kg})$

\begin{tabular}{lcccc}
\hline \multirow{2}{*}{$\begin{array}{c}\text { Final } \\
\text { Period (min) }\end{array}$} & Luminal & \multicolumn{3}{c}{ Accumulation (J net)* } \\
\hline 0 & $900^{\mathrm{a}}$ & Fluid $(\mathbf{m l})$ & Na+ $(\mathbf{m E q})$ & $\mathbf{C l}^{-}(\mathbf{m E q})$ \\
\hline 5 & $480^{\mathrm{b} * *}(5.1)$ & $+1.27(0.012)$ & $+26^{\mathrm{a}}(2.6)$ & $-3.2^{\mathrm{a}}(3.1)$ \\
10 & $475^{\mathrm{b}}(3.8)$ & $+1.50^{\mathrm{b}}(0.015)$ & $+75^{\mathrm{b}}(3.1)$ & $-3.7^{\mathrm{a}}(2.5)$ \\
15 & $480^{\mathrm{b}}(2.9)$ & $+1.60^{\mathrm{b}}(0.024)$ & $+47^{\mathrm{c}}(1.8)$ & $-58^{\mathrm{b}}(2.9)$ \\
20 & $358^{\mathrm{c}}(5.1)$ & $+1.39^{\mathrm{a}}(0.018)$ & $+36^{\mathrm{c}}(1.9)$ & $-166^{\mathrm{c}}(0.9)$ \\
30 & $325^{\mathrm{d}}(5.3)$ & $+1.03^{\mathrm{c}}(0.011)$ & $-49^{\mathrm{d}}(1.8)$ & $-207^{\mathrm{d}}(1.4)$ \\
50 & $300^{\mathrm{e}}(2.1)$ & $-0,18^{\mathrm{d}}(0.017)$ & $-221^{\mathrm{e}}(4.1)$ & $-310^{\mathrm{e}}(2.1)$ \\
70 & $300^{\mathrm{e}}(2.2)$ & $-0.30^{\mathrm{e}}(0.008)$ & $-432^{\mathrm{f}}(0.9)$ & $-391^{\mathrm{f}}(2.3)$ \\
\hline
\end{tabular}

$\mathrm{n}=10$ animals/group

* J net - positive value means net secretion (accumulated); negative value means net absorption from lumen into the body

$* *$ Mean $\pm(\mathrm{SD})$

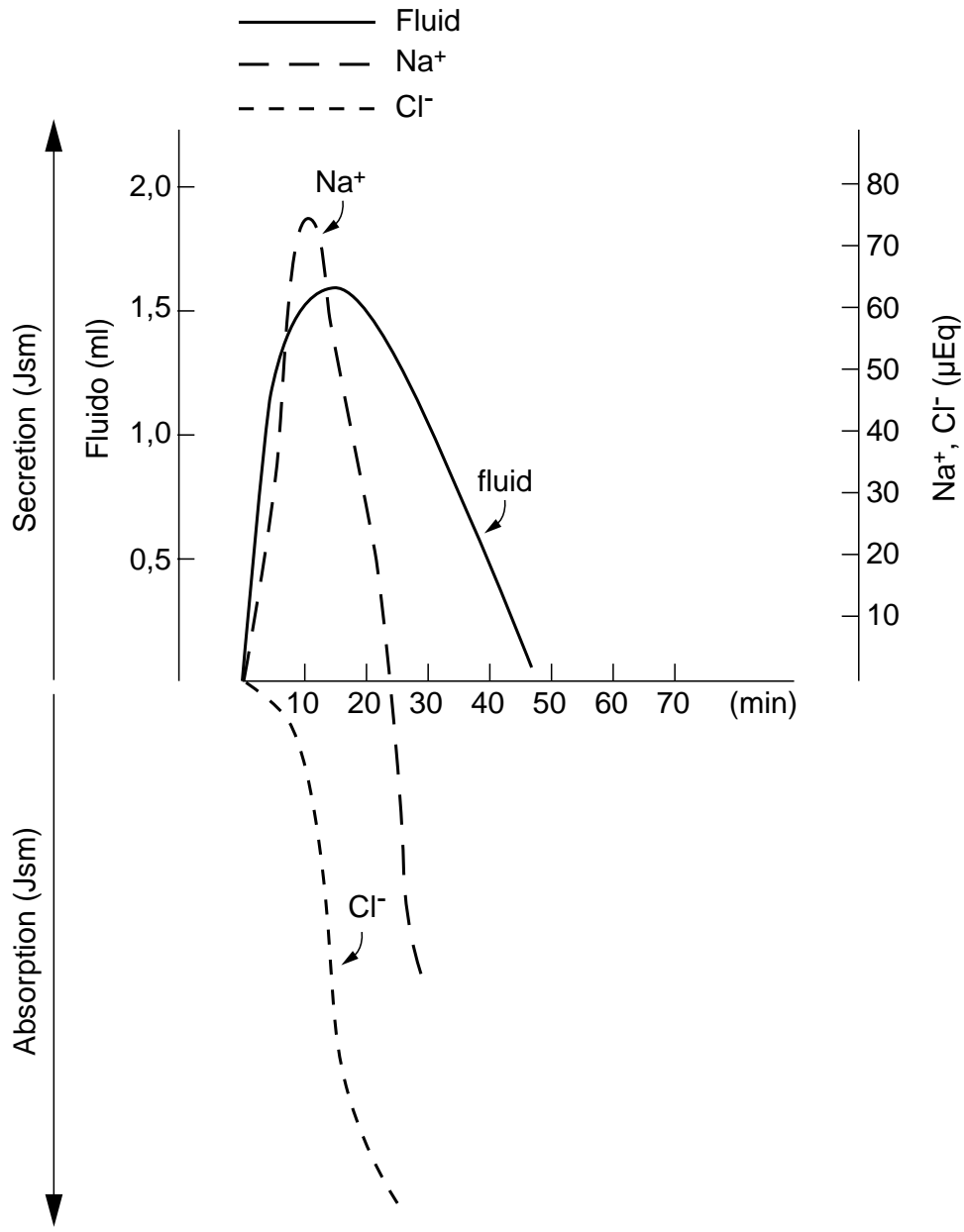

Figure 1 - Secretion and absorption of sodium and chloride from $\mathrm{NaCl}, 900 \mathrm{mOsm} / \mathrm{kg}$. Observations from 10 to $70 \mathrm{~min}$ 
Table 2 - Body weight variation of the animals of Co or R diets utilized in model II

\begin{tabular}{lcc}
\hline \multicolumn{2}{c}{ Diet } & Body weight $(\mathbf{g})$ \\
& Initial (35 days) & Final (50 days) \\
\hline Co & $63.47^{\mathrm{a}(1)}(7.89)$ & $106.9^{\mathrm{a} *}(3.2)$ \\
$\mathrm{R}$ & $63.64^{\mathrm{a}}(11.80)$ & $80.8^{\mathrm{b} *}(6.3)$ \\
\hline different letters in column: $\mathrm{P}<0.01$ in column & \\
$* \mathrm{P}<0.01$ final vs initial & \\
$(1)$ Mean $\pm(\mathrm{SD})$ & \\
$\mathrm{n}=40$ for Co group & \\
$\mathrm{n}=100$ for $\mathrm{R}$ group &
\end{tabular}

Table 3 - Net final accumulation of $\mathrm{Na}+$ and $\mathrm{Cl}$ - in the small intestine of rats fed control (Co) or restricted (R) diet after introduction of $1 \mathrm{~mL}$ hyperosmolar $900 \mathrm{mOsm} / \mathrm{kg}$ of NaCl (absorbable), or mannitol (not absorbable). Influence of acetil-b-methylcholine (Mch) in presence or not of atropine (A), or 2-4-dinitrophenol (D) - (periods of 10 minutes)

\begin{tabular}{|c|c|c|c|c|c|}
\hline \multirow[t]{2}{*}{ Diet } & \multirow{2}{*}{$\begin{array}{c}\text { Hypertonic } \\
(900 \mathrm{mOsm} / \mathrm{kg})\end{array}$} & \multirow{2}{*}{$\begin{array}{c}\text { Drug } \\
\text { interference }\end{array}$} & \multicolumn{3}{|c|}{ Accumulation $(J \text { net })^{(1)}$} \\
\hline & & & Fluid (ml) & $\mathrm{Na}^{+}(\mathrm{mEq})$ & $\mathrm{Cl}^{*}(\mathrm{mEq})$ \\
\hline $\mathrm{R}$ & $\mathrm{NaCl}$ & $\operatorname{Basal}(2)$ & $+1.3^{\mathrm{a}(3)}(0.08)$ & $+78^{(3) \mathrm{a}}(9.8)$ & $+2.2^{\text {(a) }}(7.0)$ \\
\hline $\mathrm{R}$ & $\mathrm{NaCl}$ & Mch & $+1.8^{\mathrm{b}}(0.09)$ & $+144^{\mathrm{b}}(8.8)$ & $77.5^{\mathrm{b}}(10.2)$ \\
\hline $\mathrm{R}$ & $\mathrm{NaCl}$ & $\mathrm{Mch} / \mathrm{A}$ & $+1.5^{\mathrm{b}}(0.10)$ & $+43.5^{\mathrm{c}}(6.9)$ & $+22.0^{\mathrm{c}}(6.1)$ \\
\hline $\mathrm{R}$ & $\mathrm{NaCl}$ & $\mathrm{D}$ & $+1.1^{\mathrm{a}}(0.09)$ & $+40.7^{\mathrm{c}}(6.5)$ & $-62.8^{\mathrm{b}}(3.8)$ \\
\hline $\mathrm{R}$ & $\mathrm{NaCl}$ & $\mathrm{Mch} / \mathrm{D}$ & $+1.2^{\mathrm{a}}(0.11)$ & $+27.7^{\mathrm{d}}(3.5)$ & $-70.8^{\mathrm{b}}(2.8)$ \\
\hline Co & $\mathrm{NaCl}$ & Basal & $+1.31(0.08)$ & $+41.2 *(2.2)$ & $+2.1(5.0)$ \\
\hline Co & $\mathrm{NaCl}$ & Mch & $+1.70(0.12)$ & $+81.0 *(9.5)$ & $62.1(6.2)$ \\
\hline $\mathrm{R}$ & Mannitol & Basal & $+1.5^{\mathrm{a}}(0.05)$ & $+166.0^{(\mathrm{a})}(10.1)$ & $+95.4^{(\mathrm{a})}(5.9)$ \\
\hline $\mathrm{R}$ & Mannitol & Mch & $+1.6^{\mathrm{a}}(0.04)$ & $+163.3^{(\mathrm{a})}(8.2)$ & $+78.6^{(\mathrm{a})}(8.3)$ \\
\hline $\mathrm{R}$ & Mannitol & $\mathrm{Mch} / \mathrm{A}$ & $+1.3^{\mathrm{a}}(0.09)$ & $+143.5^{\text {(a) }}(11.2)$ & $+68.0^{\text {(a) }}(9.9)$ \\
\hline $\mathrm{R}$ & Mannitol & $\mathrm{D}$ & $+1.2^{\mathrm{a}}(0.09)$ & $+158.0^{(\mathrm{a})}(11.2)$ & $+85.0^{(\mathrm{a})}(6.2)$ \\
\hline $\mathrm{R}$ & Mannitol & $\mathrm{Mch} / \mathrm{D}$ & $+1.3^{\mathrm{a}}(0.10)$ & $+175.0^{(\mathrm{a})}(9.5)$ & $+78.7^{\text {(a) }}(7.9)$ \\
\hline Co & Mannitol & Basal & $+1.45(0.09)$ & $+160.0(9.8)$ & ND \\
\hline Co & Mannitol & Much & $+1.70(0.11)$ & $+161.1(7.9)$ & ND \\
\hline
\end{tabular}

$\mathrm{n}=10$ animals/group (total 140 rats)

(1) J net - positive value means net secretion (accumulation)

- negative values means bet absorption from lumen into the body

(2) Basal- conditions, hypertonic load, or, influenced by:

mecholil (Mch), atropine (A), 2-4-dinitrophenol (D)

$\mathrm{Mch} / \mathrm{A}$ - Mch and A

Mch/D - Mch and D

(3) Mean \pm (SD)

Under hypertonic $\mathrm{NaCl}$, it occurred accumulation of $\mathrm{Na}^{+}$enhanced by effect of Mch; this effect was inhibited by A or D for $\mathrm{Na}^{+}$. As regards to $\mathrm{Cl}^{-}, \mathrm{D}$ had a significant effect as stimulator for net absorption.

Under hypertonic mannitol a net secretion of $\mathrm{Na}^{+}$or $\mathrm{Cl}^{-}$, occurred in all situations not modified by Mch, A or D.
The final $\mathrm{Na}^{+}$of $\mathrm{Cl}^{-}$in the lumen represented the sum of the initial (introduced in the lumen) plus the total $\mathrm{Na}^{+}$or $\mathrm{Cl}^{-}$ secreted, minus the absorbed amounth. In an attempt to calculate the undirectional fluxes, the influx (absorbed), Jms, was determined as: the initial (introduced) into the intestinal loop plus the final due to hypertonic effect (assumed as the final obtained by the effect of mannitol, which represents the secretion), minus the final result obtained after $\mathrm{NaCl}$.

Assuming these calculations, the final luminal content of $\mathrm{Na}^{+}\left(\mathrm{Na}^{+} \mathrm{f}\right)$ obtained was:

$\mathrm{Na}^{+} \mathrm{f}=$ Initial $+\mathrm{Jsm}-\mathrm{Jms}$

As $900 \mathrm{mOsm} / \mathrm{kg} \mathrm{NaCl}$ solution corresponds to $450 \mu \mathrm{Eq}$ of $\mathrm{Na}^{+}$and $\mathrm{Cl}^{-}$by introducing this value in the above equation:

$\mathrm{Jms}=450+\mathrm{Jsm}-\mathrm{Na}^{+} \mathrm{f}$

The results obtained from these calculations for $\mathrm{Na}^{+}$are presented in Fig. 2 and for $\mathrm{Cl}^{-}$, in Fig. 3.

The Jsm was not affected by the Mch, D or A drugs. However the Jms decreased significantly by the effect of Mch. The previous injections of A or Mch, as well as the $\mathrm{D}$ introduction in the intestinal lumen, inhibited the effect of Mch.

In the energy restricted animals (R) the final accumulation of $\mathrm{Na}+$ was enhanced in relation to Co-diet group, and this action was more evident after previous i.m. Mch.

\section{DISCUSSION}

Experimental investigation in animals, related with relevant problem of pediatric gastroenterology, as diarrhea, is an important tool, mainly by the possibility to isolate one among several variables.

In the pathophysiology of diarrhea the role of the osmoregulation, although recognized as a relevant phenomenon, it is not yet clearly understood.

New insights regarding hydrosmotic salt effect on epithelial apical membrane, the role of intracellular modulation of secretory 


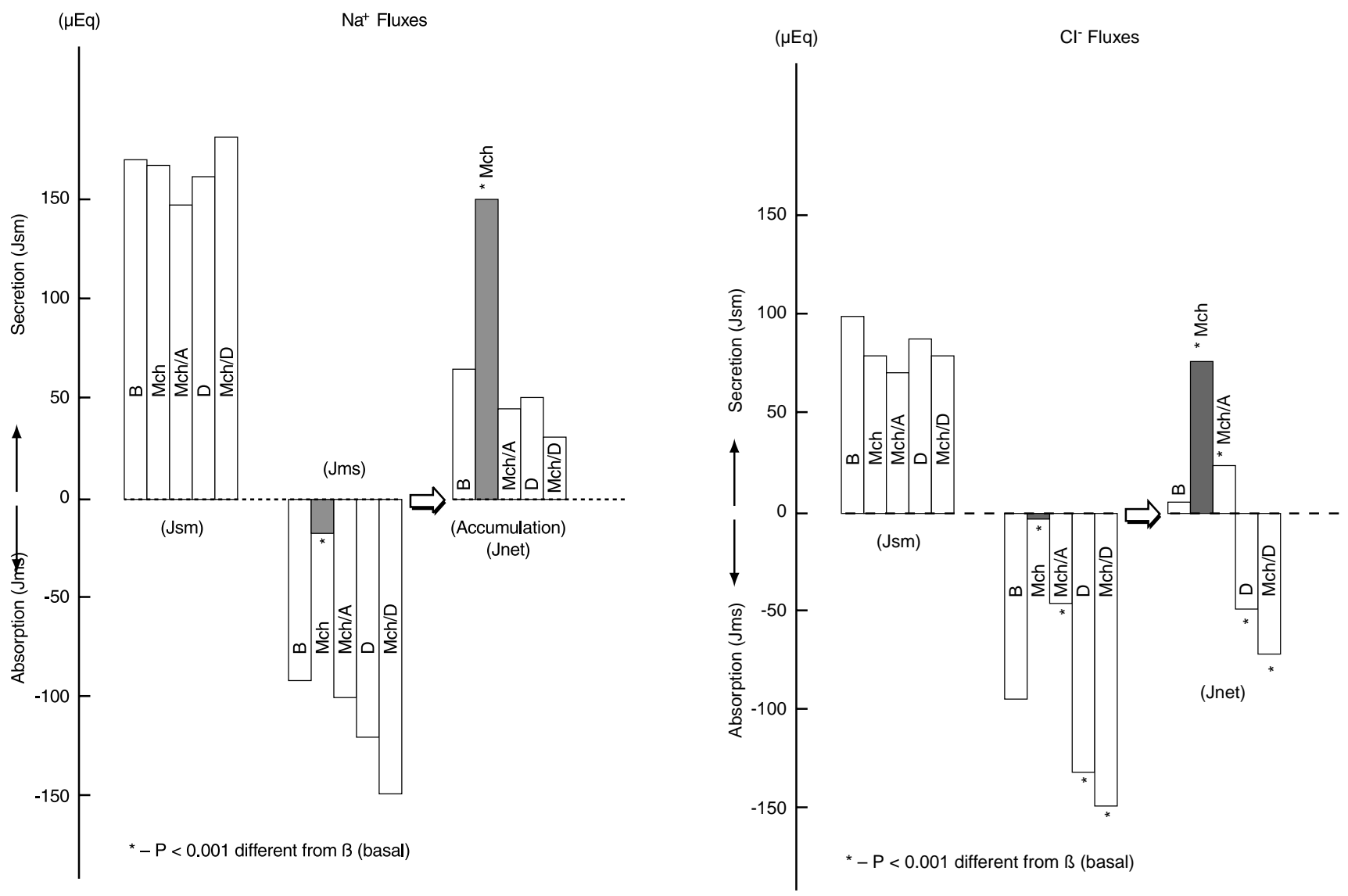

Figure 2 - Bidirectional fluxes and net transport ( $\mathrm{J}$ net). A - of sodium, and $\mathbf{B}$ - of chloride in small intestinal loops after the introduction o $1 \mathrm{~mL}$ $\mathrm{NaCl}$ or mannitol, $900 \mathrm{mOsm}(10 \mathrm{~min})$. Influence of acetyl-B-methylcholine (Mch), atropine (A), 2-4 dinitrophenol (D)

mechanisms and the participation of paracellular permeability are events that recently present a large field of speculations. Impairment in jejunal mucosal detected by biopsies from malnourished children suggests that there is a morphological basis for such liability, which structure reminds immature crypt cells ${ }^{(13)}$. With the progress in knowledge of both intestinal transport and secretion mechanisms the pathophysiology of diarrhea become more understandable in the last decades.

The present investigation has been carried out in order to study the pattern of the intraluminal small intestinal accumulation of fluid and sodium in normal and malnourished rats.
Two different experimental models were sequentialy performed as an approach to this goal.

\section{Model I - In malnourished rats}

Net absorption of sodium occurred after $20 \mathrm{~min}$, when the intraluminal osmolality decreased from 900 to $3588 \mathrm{mOsm} / \mathrm{kg}$. KAWAKAMI et al. ${ }^{(12)}$ detected sodium net secretion with perfused solution of $370 \mathrm{mOsm} / \mathrm{kg}$. However the ion chloride was absorbed from the very beginning, suggesting that sodium efflux must be combined with the efflux of another anion than chloride. The intraluminal contents became isotonic only after $30 \mathrm{~min}$.
The maximum accumulation period for $\mathrm{Na}^{+}$ occurred at 10 minutes (Table 1, Fig. 1).

\section{Model II}

The second experiment was performed with hyperosmolar challenges for 10 minutes. As a tool to speculate more about the mechanisms involved, some factors were introduced as Mch. Mch ia a p-sympathicomimetic drug, and as it was observed by the results presented in Table 2 , it increased the final net secretion of $\mathrm{Na}^{+}$and $\mathrm{Cl}^{-}$.

The efflux was assumed as the results obtained by thew experiments performed with mannitol which is not absorbed by the intestine, 
and so maintaining the hyperosmolality in the lumen for a longer period than $\mathrm{NaCl}$. If the efflux was not changed by the factors essayed (Mch, A or D) but the net accumulation was impaired, this fact suggests that the influx, or the intestinal absorption was altered in these situations. As the $\mathrm{Na}^{+}$and $\mathrm{Cl}^{-}$accumulation in basal situation were of $78 \mu \mathrm{Eq}$ and $2.2 \mu \mathrm{Eq}$, respectively, and after Mch i.m. injection these results were higher: 144 and $77.5 \mu \mathrm{Eq}$, it is possible to conclude that the intestinal absorption of these ions were reduced (Table 2, Fig. 1), and taking in account that the Mch effect was inhibited by A, probably the Mch effect occurred by a cholinergic pathway. ButD-also behaved as Mch inhibitor, and so, it is suggested that Mch acted through an active mechanism inhibiting the intestinal absorption of $\mathrm{Na}^{+}$and $\mathrm{Cl}^{-}$, perhaps with cellular mediators.

ISAACS et al. ${ }^{(9)}$ found that cholinergic agents decrease absorption causing secretion across the epithelium while anticholinergic drugs increase absorption and probably its action occurred mainly in the crypt region ${ }^{(2)}$, perhaps mediated by VIP and AMPc, involving adrenergic receptors ${ }^{(3)}$.

Dinitrophenol enhanced the $\mathrm{Cl}^{-}$absorption (Table 3) and probably this was a results of the decreased electrical potential difference (pd) between the two compartments, lumen and blood observed in our previous, not published investigations.

According to studies of JACKSON ${ }^{(10)}$, the Na net efflux may be originated from unabsorbed sodium initially present in the lumen, or from $\mathrm{Na}$ of the extracellular space of the unstirred layer of fluid or after exit from the tissue itself; it could also possible to be derived directly from a vascular to lumen movement by an osmolar intestinal perturbation.

It was detected a significant increase in the final net secretion or accumulation of sodium, both with or without Mch i.m. injection, remarkable in energy restricted (R) in relation to Co animals.

The fact that the animals under energy restriction $(\mathrm{R})$ presented more evident "net secretion" could be assumed as a final result of decreased re-absorption of the secreted sodium. It is possible to suggest that energy restriction delays the intestinal sodium absorption and this effect could be one of the factors that induces diarrhea in malnutrition. Hydragogue drugs in certain concentrations appear to have the ability to make the intracellular junctions leaky and then standing osmotic gradient cannot be maintained further ${ }^{(17)}$. FLEMING(7) says that rats deprived of protein have been shown to have increased mucosal permeability to ferritin and adenovirus raising the possibility of a functional deterioration of intracellular functions. NZEGWU and LEVIN ${ }^{(16)}$ detected in rats an increase of the intestinal secretion in malnutrition, and this effect was perturbed by calcium but not by AMPc.

The use of rice-based oral rehydration reduction secretions in intestinal crypts through reducing $\mathrm{cAMP}^{(14)}$ and probably by actively inhibiting the chloride channel ${ }^{(8)}$ must be well evaluated before its adoption as the preferred oral rehydration solutions.

In the present study it is possible that the imposed hyperosmolar load to energy deprived rats could slow tight intercellular junctions.

\section{SPECULATION}

As a speculation it is possible to suggest that in the malnutrition, an intestinal challenge (as hyperosmolality) induces more secretion than in normal nutrition because of the reduced capacity of absorption. Other factors are involved in the accumulation of $\mathrm{Na}^{+}$and fluid as cholinergic or secretory mediators. If this could be extrapolated to human beings, it would possible to suggest that malnourished children are more vulnerable to intestinal challenges as hyperosmolality and modulators of secretion developing diarrhea easier than normal ones.

Angelis RC de, Campos JVM, Rogano RN, Giuli GG, Terra ICM, Scialfa JH, Klemps-Filho I. Aumento de secreção em relação à absorção na desnutrição. Estudo por carga hiperosmolar em ratos. Arq Gastroenterol, São Paulo, 36(4):220-226, 1999.

RESUMO - Dois modelos experimentais foram usados para estudar o efeito de uma carga hiperosmolar nos fluxos bidirecionais de sódio e cloro no intestino de animais em restrição energética. No modelo $\mathrm{I}, 1 \mathrm{~mL}$ de $\mathrm{NaCl} 900 \mathrm{mOsm}$ foi introduzido no intestino delgado e deixado de 5 a 70 minutos, a fim de determinar o tempo para ocorrer a maior secreção de sódio, o que se observou aos 10 minutos. No modelo II, os fluxos birecionais de sódio e cloro foram determinados em ratos em restrição energética após carga hipertônica, aos 10 minutos. Foram estudados efeitos de: inibidor metabólico (2-4 dinitrofenol) e farmacológicos. Sugere-se que na má nutrição ocorre impedimento da reabsorção intestinal, favorecendo aumento resultante de secreção.

DESCRITORES - Secreções intestinais. Distúrbios nutricionais. Sódio. Absorção intestinal. Ratos. 


\section{REFERENCES}

1. Association of Official Analytical Chemists. Official methods of analysis of AOAC. 11 ed. Washington DC., 1970. p.102.

2. Browning JG, Hardcastle J. Hardcastle PT. Localization of the effect of acetylcholine in regulating intestinal ion transport. J Physiol, 281:15, 1978.

3. Cassuto J, Jodal M, Sjorvall H. Nervous control of intestinal secretion. Clin Res Rev, 1:11, 1981

4. Christensen J. Gastrointestinal motility: the regulation of nutrient delivery. In: Green M, Greene ML, ed. The role of the gastrointestinal tract in nutrient delivery. New York, Academic Press, 1984. p.83-106. (Bristol-Myers Nutrition Symposia).

5. Commonwealth Bureau of Nutrition 1979. Livestock feeds and feeding. Nutr Abstr Rev, 49:413, 1979.

6. De Angelis RC. Mechanism of intestinal absorption of thiamine. Arq Gastroenterol, 14:135, 1977.

7. Fleming CR, Phillips SF. Response of the small intestine to nutritionally deficiencies. In: Chadwick VS, Phillips S, ed. Gastroenterology 2. Small intestine. London, Butterworth, 1982. p.322-44.

8. Goldberg ED, Saltzman JR. Rice inhibits intestinal secretions. Nutr Rev, 54:36, 1998 .

9. Isaacs PET, Corbett CL, Riley S, Hawker PC. In vitro behaviour of human intestinal mucosa. The influence of acetylcholine on ion transport. In: Reed NW, ed. The relation between intestinal motility ands intestinal transport. Clin Res Rev, 1:73, 1981.
10. Jackson MJ. Drug transport across gastrointestinal epithelia. In Johnson LR, ed. Physiology of the gastrointestinal tract. 2.ed. New York, Raven Press, 1987. p.1599-621.

11. Kagnoff MF. Immunology and allergic responses of the bowel. In: Green $\mathrm{M}$, Greene ML, ed. The role of the gastrointestinal tract in nutrient delivery. New York, Academic Press, 1984. p.239-57. (Bristol-Myers Nutrition Symposia).

12. Kawakami E, Fagundes-Neto U. Transepitelial transport of water, sodium and glucose of oral hydration solutions, in jejunal loops of rats submitted to perfusion in vivo. Arq Gastroenterol, 30:99, 1993.

13. Lipkim M. Proliferation and differentiatioin of gastrointestinal cells in health and disease. In: Green M, Greene ML, ed. The role of the gastrointestinal tract in nutrient delivery. New York, Academic Press, 1984. p.17-37. (Bristol-Myers Nutrition Symposia).

14. MacLeod R, Bennett R, Hamilton J. Inhibition of intestinal secretion by rice. Lancet, 446:90, 1995.

15. Meyers A. Modern management of acute diarrhea. Am Fam Physician, 51:1103, 1995.

16. Nzegwur HC, Levin RJ. Dietary reduction increases secretion in rat distal colon. Proc Nutr Soc, 49:178A, 1990.

17. Rummel W, Nell G, Warnitschke R. Action mechanism of antiabsorptive and hydragogue drugs. In: Czaky T, ed. Intestinal absorption and malabsorption. New York, Raven Press, 1975. p.209-27.

18. Wenland BE, Arbus GS. Oral fluid therapy sodium and potassium content and osmolality of some commercial "clear" soups. juices and beverages. Can Med Assoc J, 121:564, 1989. 